\title{
High Expression of p21 as a Potential Therapeutic Target in Ovarian Clear-cell Carcinoma
}

\author{
YUKI MINAGAWA $^{1,2}$, KOUSUKE ISHINO ${ }^{1}$, RYUICHI WADA ${ }^{1,3}$, MITSUHIRO KUDO $^{1}$, \\ ZENYA NAITO $^{1,3}$, TOSHIYUKI TAKESHITA ${ }^{2}$ and RYUJI OHASHI ${ }^{1,3}$ \\ ${ }^{1}$ Department of Integrated Diagnostic Pathology, Nippon Medical School, Tokyo, Japan; \\ ${ }^{2}$ Department of Obstetrics and Gynecology, Nippon Medical School, Tokyo, Japan; \\ ${ }^{3}$ Department of Diagnostic Pathology, Nippon Medical School Hospital, Tokyo, Japan
}

\begin{abstract}
Background/Aim: DNA damage response (DDR), wherein $p 21$ is a cell fate determinant, is a potential cancer therapeutic target. Molecular expression during DDR was explored in ovarian clear-cell carcinoma (CCC). Materials and Methods: CHK1, CHK2, TP53 and p21 expression in DDR was examined using immunostaining in surgical sections of CCC $(n=22)$. Molecular alterations in two types of CCC cell lines, JHOC-5 and JHOC-9, were investigated using western blot analysis. Results: Expression of DDR-associated molecules was noted in most patients. While high p21 expression was found in half of the patients, the remaining patients exhibited low p21 expression. Treatment with UC2288, a p21 inhibitor, attenuated proliferation of both cell lines, more prominently in JHOC-9, resulting in reduced viability and subsequent apoptosis. Conclusion: 21 Inhibitor induced cell death in cells with high p21 expression, suggesting that 21 suppression can be a therapeutic strategy to treat patients with CCC.
\end{abstract}

The DNA damage response (DDR) plays an important role in the maintenance of genetic integrity in normal as well as in carcinoma cells (1). When DNA is damaged, sensors such as poly (ADP ribose) polymerase (PARP) and $80 \mathrm{kDa}$ Ku protein (KU80) activate ataxia-telangiectasia mutated (ATM) and ATM- and RAD3-related (ATR). Subsequently, transducers, checkpoint kinase 1 (CHK1) and checkpoint kinase 2 (CHK2),

This article is freely accessible online.

Correspondence to: Kousuke Ishino, Department of Integrated Diagnostic Pathology, Nippon Medical School, 1-1-5 Sendagi, Bunkyo-ku 113-8602, Tokyo, Japan. Tel: +81 338222131, e-mail: kishino@nms.ac.jp

Key Words: Ovarian clear-cell carcinoma, DNA damage response, cisplatin, p21. organize cell-cycle arrest and repair of damaged DNA. Tumour protein p53 (TP53) and 21-kDa protein (p21) suppress the cell cycle, and damaged DNA is repaired. If the DNA repair is incomplete, the cell undergoes apoptosis. The susceptibility of tumours to chemotherapeutic agents, such as cisplatin, cisdiamminedichloridoplatinum(II), is regulated by molecules expressed during DDR $(1,2)$, which can be a target of molecular targeting therapy $(1,3)$. p21, one of the molecules involved in DDR, is an inhibitor of cyclin-dependent kinase (CDK) and a key regulator of the cell cycle in DDR (4-6). It is also suggested that p21 regulates apoptotic cell death (4-7).

Epithelial ovarian cancer (EOC) is the most lethal malignancy, and a leading cause of gynaecological cancerrelated deaths worldwide. Clear-cell carcinoma (CCC), a subtype of EOC, accounts for more than $20 \%$ of EOC in Japan (8). Compared to other subtypes, the prognosis of patients with CCC is poor due to a high recurrence rate and chemotherapy resistance $(9,10)$. Owing to its aggressive behaviour, patients with CCC predominantly follow an unfavourable clinical course.

The molecules highly expressed during DDR in CCC have been described in literature (3). For example, the expression levels of CHK1, CDK2, and p27 correlated with the degree of chemoresistance in patients with CCC $(11,12)$. Although understanding the functional state of DDR is beneficial to predicting sensitivity to treatment, molecular expression in DDR has not been fully elucidated in CCC due to the limited number of studies.

In the present study, we explored the clinicopathological significance of DDR in CCC. The expression of CHK1, CHK2, TP53 and p21 were examined by immunohistochemical (IHC) staining of surgical sections of CCC. As a DNA-damaging agent, we chose cisplatin in order to observe its effect on molecular expression in DDR using two types of CCC cell lines. The effect of UC2288, an attenuator of p21 (13-15), was also examined to investigate how functional modulation of p21 may alter CCC cell viability. 


\section{Materials and Methods}

Cases of CCC. A total of $22 \mathrm{CCC}$ cases were retrieved from pathological records in the archives at the Department of Diagnostic Pathology, Nippon Medical School Hospital, and used for histological and IHC studies. These cases underwent ovarian resection from 2013 to 2019. Histology was reviewed by two investigators (YM and RW). The clinicopathological features of the cases are listed in Table I. Pathological T-factor and lymph node metastasis were reviewed. The study was approved by the Ethical Committee of Nippon Medical School Hospital (Approval no. 3006-944). Written informed consent was obtained from all patients.

IHC staining and semi-quantitative evaluation. IHC staining of molecules involved in DDR was performed using the polymer-based two-step method. Briefly, paraffin sections were deparaffinized and hydrated in phosphate-buffered saline (PBS). Following blocking of endogenous peroxidase, sections were pre-treated with appropriate buffer, if necessary. Thereafter, sections were incubated with antibodies against CHK1, CHK2, TP53, and p21 at $4^{\circ} \mathrm{C}$ overnight (Table II). Following washing three times with PBS, sections were subsequently incubated with MAX-PO (cat. no. 424134 Mouse, 424144 Rabbit; Nichirei Biosciences Inc., Tokyo, Japan). Peroxidase activity was visualized with diaminobenzidine (DAB), using the DAB Substrate Kit (Nichirei Biosciences Inc.).

The expression of molecules was evaluated by a semiquantitative method. For CHK1, CHK2, and TP53, nuclear staining was considered as a positive reaction. Case were considered positive when $\geq 20 \%$ of tumour cells showed nuclear staining, whereas cases were considered negative when positive cells were $<20 \%$.

IHC staining of p 21 was evaluated by a semi-quantitative method (16). Nuclear staining was considered a positive reaction. The intensity score was divided into four grades as follows: When no staining was found in carcinoma cells, intensity was scored 0 ; for standardization, moderate staining was given a score of 2. A score of 1 was defined as clear but staining weaker than that of cells with a score of 2. A score of 3 was defined as staining stronger than that of a score of 2. Thereafter, the proportion of positive cells of each score intensity was evaluated as a percentage in $10 \%$ increments. The total score was calculated using the formula: $1 \times$ (proportion of cells with score 1$)+2 \times$ (proportion of cells with score 2$)+3 \times$ (proportion of cells with score 3 ). The staining was reviewed in a blind manner two investigators (YM and RW). When discrepancy in scoring occurred, the two Authors discussed the results and the most appropriate value was determined.

Cell culture. Human CCC of ovary cell lines JHOC-5 (RBRCRCB1520) and JHOC-9 (RBRC-RCB2226) were obtained from RIKEN BioResource Center (Ibaraki, Japan). Cells were cultured in a mixture of Dulbecco's modified Eagle's medium and Ham F12 medium (Thermo Fisher Scientific, Rockford, IL, USA) supplemented with $10 \%$ foetal bovine serum (Nichirei Biosciences, Inc.) and $0.1 \mathrm{mM}$ non-essential amino acids (Thermo Fisher Scientific) at $37^{\circ} \mathrm{C}$.

Counting of cultured cells treated with cisplatin and UC2288. JHOC- 5 and JHOC- 9 cells were plated in 96-well plates at a density of $1 \times 10^{4}$ cells/well, respectively. Cells were cultured at $37^{\circ} \mathrm{C}$ for 24 h. Thereafter, $10 \mu \mathrm{g} / \mathrm{ml}$ cisplatin (FUJI Film Wako Pure Chemical Corp., Osaka, Japan) with/without $10 \mu \mathrm{M}$ UC2288 (Sigma-Aldrich;
Merck KGaA, St. Louis, MO, USA) were added to culture medium, and the cells were cultured at $37^{\circ} \mathrm{C}$. Viable cells were determined using Cell Counting Kit-8 (DOJINDO Molecular Technologies, Inc., Kumamoto, Japan) at $0,24,48$, and $72 \mathrm{~h}$. Experiments were performed in triplicate. The viable cells were indicated as absorbance at $450 \mathrm{~nm}$.

Preparation of protein samples. Cultured cell of JHOC-5 and JHOC-9 were plated in $100 \mathrm{~mm}$ dish at density of $5 \times 10^{5}$ cells/dish and $1 \times 10^{6}$ cells/dish, respectively. The cells were cultured at $37^{\circ} \mathrm{C}$ for $72 \mathrm{~h}$. Then, $10 \mu \mathrm{g} / \mathrm{ml}$ cisplatin and $10 \mu \mathrm{M} \mathrm{UC} 2288$ were added to the culture medium, and cells cultured at $37^{\circ} \mathrm{C}$ for $24 \mathrm{~h}$. Thereafter, cells were washed three times with PBS and subsequently lysed in $50 \mathrm{mM}$ Tris- $\mathrm{HCl}(\mathrm{pH} 7.6) / 0.5 \%$ sodium dodecylsulfate and sonicated in iced water for $60 \mathrm{~min}$. Protein samples were used for western blot analysis.

Western blot analysis. Protein samples were mixed with $2 \times$ Laemmli Sample Buffer (Bio-Rad Laboratories, Inc., Hercules, CA, USA) and boiled at $95^{\circ} \mathrm{C}$ for $10 \mathrm{~min}$. Protein samples were electrophoresed in 5-20\% polyacrylamide gel (e-PAGEL, ATTO Corporation, Tokyo, Japan) and transferred onto a polyvinylidene difluoride membrane. Following blocking with 5\% skim milk in Tris-buffered saline $/ 0.05 \%$ Tween 20 at room temperature for 30 $\mathrm{min}$, the membrane was incubated with the antibodies listed in Table II at $4^{\circ} \mathrm{C}$ overnight. Following washing with $25 \mathrm{mM}$ Tris-HCl (pH8.0)/150 mM NaCl/0.01\% Triton X, membranes were incubated with horseradish peroxidase-conjugated anti-mouse immunoglobulin (dilution, 1:10,000) or anti-rabbit immunoglobulin (dilution, 1:10,000, both from American Qualex Scientific Products, Inc., San Clemente, CA, USA) at room temperature for $1 \mathrm{~h}$. Peroxidase activity was detected as chemiluminescence using SuperSignal West Dura Extended Duration Substrate (Thermo Fisher Scientific).

Preparation of cell block and IHC staining. Cells were plated in 150 $\mathrm{mm}$ dishes and cultured at $37^{\circ} \mathrm{C}$ for $96 \mathrm{~h}$. Thereafter, $10 \mu \mathrm{g} / \mathrm{ml}$ cisplatin and $10 \mu \mathrm{M} \mathrm{UC} 2288$ were added to the medium, and cells were cultured at $37^{\circ} \mathrm{C}$ for $24 \mathrm{~h}$. Cells were collected with a scraper and transferred to $15 \mathrm{ml}$ conical tubes. Following centrifugation at $400 \times g$ at $4^{\circ} \mathrm{C}$ for $5 \mathrm{~min}$, the supernatant was removed, and cell pellets were fixed in $10 \%$ buffered formalin. Cell pellets were processed with ethanol and xylene and embedded into paraffin. IHC staining was performed using the same method described in previous sections using antibody against cleaved caspase- 3 at $4{ }^{\circ} \mathrm{C}$ overnight (Table II).

Statistical analysis. All data are expressed as the mean \pm standard deviation. The data of two groups were compared by the MannWhitney $U$-test. The data of three or more groups were compared by the Kruskal-Wallis test followed by Dunn's post-hoc test. All statistical analyses were performed using $\mathrm{R}$ (The R Foundation, https://www.r-project.org). A value of $p<0.05$ was considered to indicate statistical significance.

\section{Results}

IHC of DDR pathway proteins in patients with CCC. The molecular expression of CHK1, CHK2, TP53, and p21 during DDR are shown in Figure 1, and the results are summarized in Table I. Most CCC cases were at stage I at 
Table I. Clinicopathological characteristics and immunohistochemical results of the cases of clear-cell carcinoma of the ovary.

\begin{tabular}{|c|c|c|c|c|c|c|c|c|c|c|}
\hline $\begin{array}{l}\text { Case } \\
\text { no. }\end{array}$ & $\begin{array}{l}\text { Age (years) } \\
\text { at diagnosis }\end{array}$ & TNM & Stage* & CHK1 & CHK2 & TP53 & p21 & p21 score & $\begin{array}{l}\text { Time of } \\
\text { recurrence }\end{array}$ & Outcome \\
\hline 1 & 55 & pT3aNOM0 & IIIA2 & + & + & + & High & 200 & 2 Months & DOD, 4 months \\
\hline 2 & 48 & pT1cN0M0 & $\mathrm{IC}(1)$ & + & + & - & High & 210 & - & \\
\hline 3 & 56 & pT1cN0M0 & $\mathrm{IC}(1)$ & + & + & + & Low & 100 & - & \\
\hline 4 & 49 & pT1cNOM0 & $\mathrm{IC}(1)$ & + & + & + & High & 210 & - & \\
\hline 5 & 40 & pT1cN0M0 & $\operatorname{IC}(3)$ & + & + & + & High & 200 & - & \\
\hline 6 & 43 & pT1aN0M0 & IA & + & + & + & High & 240 & - & \\
\hline 7 & 67 & pT1cN0M0 & $\mathrm{IC}(1)$ & + & + & - & Low & 30 & - & \\
\hline 8 & 46 & pT1aN0M0 & IA & + & + & + & Low & 20 & - & \\
\hline 9 & 79 & pT1aN0M0 & IA & - & + & - & Low & 110 & - & \\
\hline 10 & 53 & pT1c3N0M0 & IC3 & + & + & + & High & 270 & - & \\
\hline 11 & 62 & pT1c1N0M0 & IC1 & + & + & + & Low & 170 & - & \\
\hline 12 & 69 & pT1cNXM0 & $\mathrm{IC}(1)$ & + & + & + & Low & 30 & - & \\
\hline 13 & 78 & pT1cN0M0 & $\mathrm{IC}(3)$ & + & + & + & High & 230 & - & DOOD, 3 months \\
\hline 14 & 58 & pT1cN0M0 & $\operatorname{IC}(1)$ & + & + & + & Low & 150 & - & \\
\hline 15 & 65 & pT1aN0M0 & IA & + & + & + & High & 240 & - & \\
\hline 16 & 60 & pT1c3N0M0 & IC3 & + & + & + & High & 230 & - & \\
\hline 17 & 53 & pT3cNXMX & IIIC & - & + & + & High & 230 & 36 Months & \\
\hline 18 & 62 & pT3bNXM0 & IIIB & + & + & + & High & 260 & - & \\
\hline 19 & 48 & pT1cN0M0 & $\mathrm{IC}(2)$ & + & + & + & Low & 180 & - & \\
\hline 20 & 58 & pT1aN0M0 & IA & + & + & + & Low & 20 & - & \\
\hline 21 & 39 & pT1c3N0M0 & IC3 & + & + & + & Low & 140 & 9 Months & DOD, 15 months \\
\hline 22 & 59 & pT1c1NXM0 & IC1 & + & + & + & Low & 10 & 70 Months & \\
\hline
\end{tabular}

DOD: Died of disease; DOOD: died of other disease; High: score $\geq 200$; Low: score <200. *International Federation of Gynecology and Obstetrics (FIGO) staging classification 2014 (26).

Table II. The list of antibodies used in the present study,

\begin{tabular}{|c|c|c|c|c|c|c|}
\hline \multirow[b]{2}{*}{ Antibody } & \multirow[b]{2}{*}{ Cat. no. } & \multirow[b]{2}{*}{ Clone no. } & \multirow[b]{2}{*}{ Company } & \multicolumn{2}{|c|}{ Dilution } & \multirow[b]{2}{*}{ Pretreatment } \\
\hline & & & & WB & $\mathrm{IHC}$ & \\
\hline CHK1 & $2360 \mathrm{~S}$ & & Cell Signaling Technology & $1: 1000$ & $1: 500$ & $121^{\circ} \mathrm{C}, 15 \mathrm{~min}, \mathrm{pH} 9.0$ \\
\hline p-CHK1 & $12302 \mathrm{~S}$ & & Cell Signaling Technology & 1:1000 & - & - \\
\hline CHK2 & $6334 \mathrm{~S}$ & & Cell Signaling Technology & $1: 1000$ & $1: 1000$ & $121^{\circ} \mathrm{C}, 15 \mathrm{~min}, \mathrm{pH} 6.0$ \\
\hline p-CHK2 & $2197 \mathrm{~S}$ & & Cell Signaling Technology & 1:1000 & - & - \\
\hline TP53 & DO-7 & DO-7 & Agilent Technologies & $1: 1000$ & $1: 200$ & $121^{\circ} \mathrm{C}, 15 \mathrm{~min}, \mathrm{pH} 6.0$ \\
\hline p21(WAF1) & OP64 & EA10 & Sigma-Aldrich; Merck KGaA & $1: 100$ & $1: 100$ & $121^{\circ} \mathrm{C}, 15 \mathrm{~min}, \mathrm{pH} 6.0$ \\
\hline Cleaved caspase- 3 & $9661 \mathrm{~S}$ & & Cell Signaling Technology & $1: 1000$ & $1: 300$ & $121^{\circ} \mathrm{C}, 15 \mathrm{~min}, \mathrm{pH} 6.0$ \\
\hline$\beta$-Actin & A5316 & AC-74 & Sigma-Aldrich; Merck KGaA & $1: 10000$ & - & - \\
\hline
\end{tabular}

Cat. no., Catalogue number; IHC, immunohistochemistry; WB, western blot.

the time of surgery. Recurrence was noted in only four cases. CHK1 expression was found in 20 cases $(90.9 \%)$, and the complete loss of CHK2 expression was found in none $(0 \%)$. TP53 expression was noted in 19 cases $(86.4 \%)$. Based on the p21 IHC results, we stratified cases into groups with high (score $\geq 200$ ) and low (score $<200$ ) expression. Eleven cases $(50 \%)$ were in the high expression group and 11 were in the low expression group. In the high group, nuclei were strongly positive for $\mathrm{p} 21$, while a faint positive nuclear reaction was observed in the low group.
Expression and phosphorylation of proteins in cultured CCC cells. The expression and phosphorylation state of CHK1, CHK2, TP53, and p21 after cisplatin treatment were examined by western blot analysis in cultured CCC cells (Figure 2A). CHK1, CHK2, TP53, and p21 were expressed in untreated JHOC-5 and JHOC-9 cells. The expression level of TP53 was higher in JHOC-9 than in JHOC-5 cells. Treatment with $10 \mu \mathrm{g} / \mathrm{ml}$ cisplatin for $24 \mathrm{~h}$ induced phosphorylation of CHK1 and CHK2 in both JHOC-5 and JHOC-9 cells (Figure 2A). An increase in the expression 

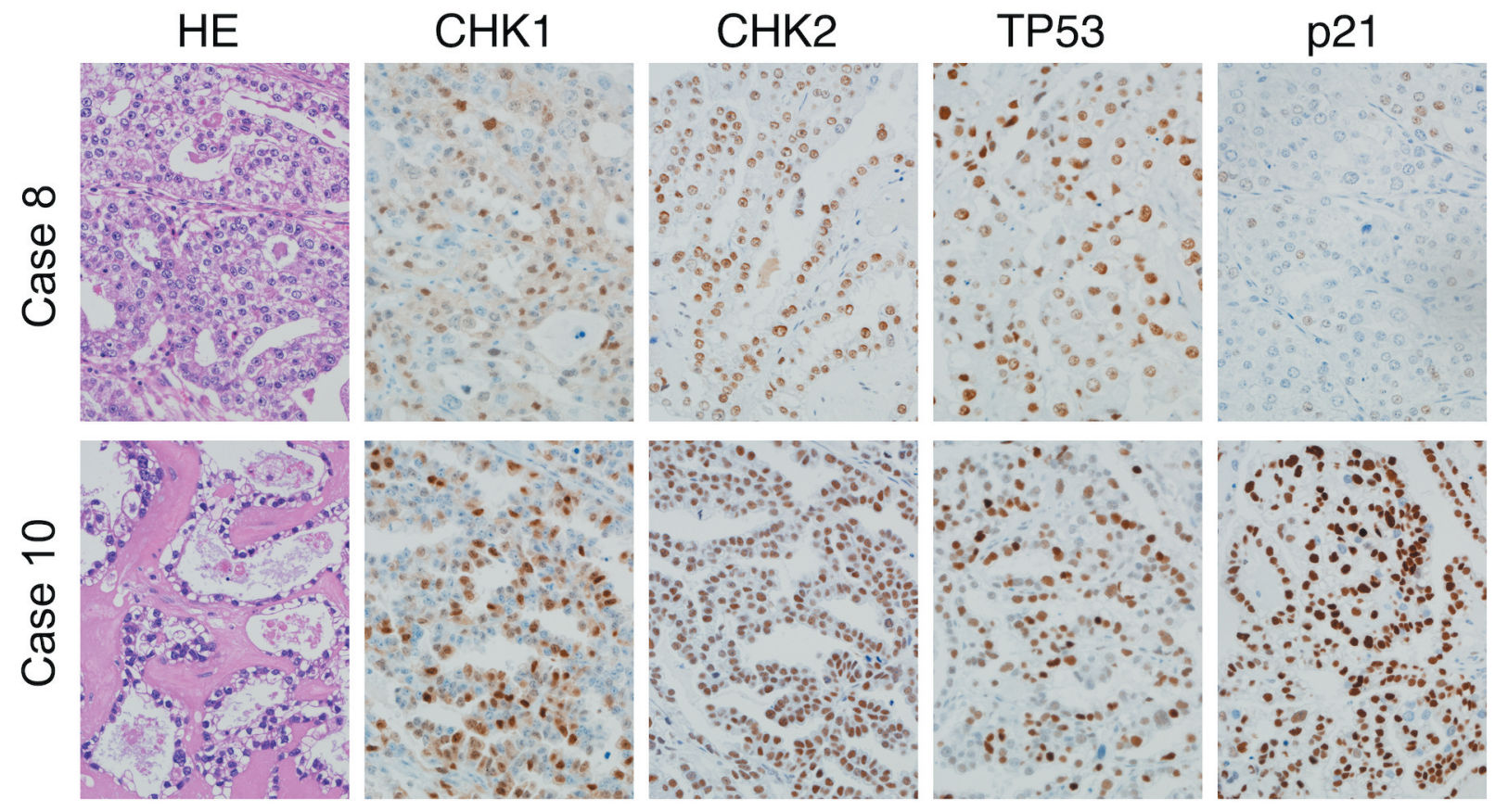

Figure 1. Representative images of immunostaining for checkpoint kinase 1 (CHK1), checkpoint kinase 2 (CHK2), tumour protein p53 (TP53) and p21 in clear-cell carcinoma cases. Significant expression of CHK1, CHK2, and TP53 was noted for the majority of these cases. In contrast, p21 expression levels by immunohistochemistry were categorized as low (score $=20$, case 8) and high (score $=270$, case 10). Original magnification $\times 400$.

level of TP53 was noted after cisplatin treatment of both cell lines. Prior to treatment, p21 expression was higher in JHOC-9 cells, while its expression was minimal in JHOC-5 cells. Cisplatin treatment had a mild suppressive effect on JHOC-9 cells, preserving significant p21 expression.

IHC expression and location of TP53 and p21 before and after cisplatin treatment. TP53 and p21 expression was examined in cell blocks (Figure 2B). TP53 was sporadically positive in untreated JHOC-5 and JHOC-9 cells, and the number of positive cells increased after cisplatin treatment in both groups. Regarding p21, a clonal positive reaction was evident in untreated JHOC-9 cells compared to JHOC-5 cells. The nuclear expression of p21 in JHOC-9 cells remained high even after cisplatin treatment, whereas the number of $\mathrm{p} 21$ positive cells increased in the JHOC-5 cell line.

Collectively, the above results using cell culture and cell block indicated that the sensors and transducers we examined in the DDR pathway were operational in two types of cultured CCC cells. Notably, the expression pattern of p21 was different between JHOC-5 and JHOC-9 cells; p21 was highly expressed in JHOC-9 cells regardless of cisplatin treatment. Hence, we subsequently performed the study using UC2288, an attenuator of p21.

Susceptibility of cultured cells to cisplatin and UC2288. Cultured cells were treated with either cisplatin or UC2288 alone, or a combination of cisplatin and UC2288. The concentrations of cisplatin and UC2288 were $10 \mu \mathrm{g} / \mathrm{ml}$ and $10 \mu \mathrm{M}$, respectively. In both cultured cell lines, proliferation was inhibited by treatment with cisplatin alone, and was suppressed to a greater extent by UC2288 alone, and by cisplatin plus UC2288 (Figure 3). Notably, JHOC-9 underwent cell death after treatment with UC2288 alone, or combined with cisplatin (Figure 3). No significant difference was observed in the suppressive effect between UC2288 when used alone and in combination with cisplatin, suggesting that combining these two agents did not result in a synergistic effect.

Cell fate-determinant proteins in cultured cells and cell block with cisplatin and UC2288 treatment. TP53 and p21 expression was investigated in cultured cells treated with either cisplatin or UC2288 alone, or their combination. p21 expression was eliminated by UC2288 in JHOC- 5 cells. In JHOC-9 cells, the expression level of p21 was reduced by UC2288 with and without cisplatin (Figure 4A). Caspase-3 activation was examined in cell blocks (Figure 4B). No significant positivity for cleaved caspase-3, the active form of caspase-3, was noted in JHOC-5 cells treated with agents alone nor in combination. In contrast, the number of cleaved caspase-3-positive JHOC-9 cells significantly increased after UC2288 treatment with and without cisplatin. Cisplatin alone induced caspase- 3 activation in a few JHOC-9 cells. These 

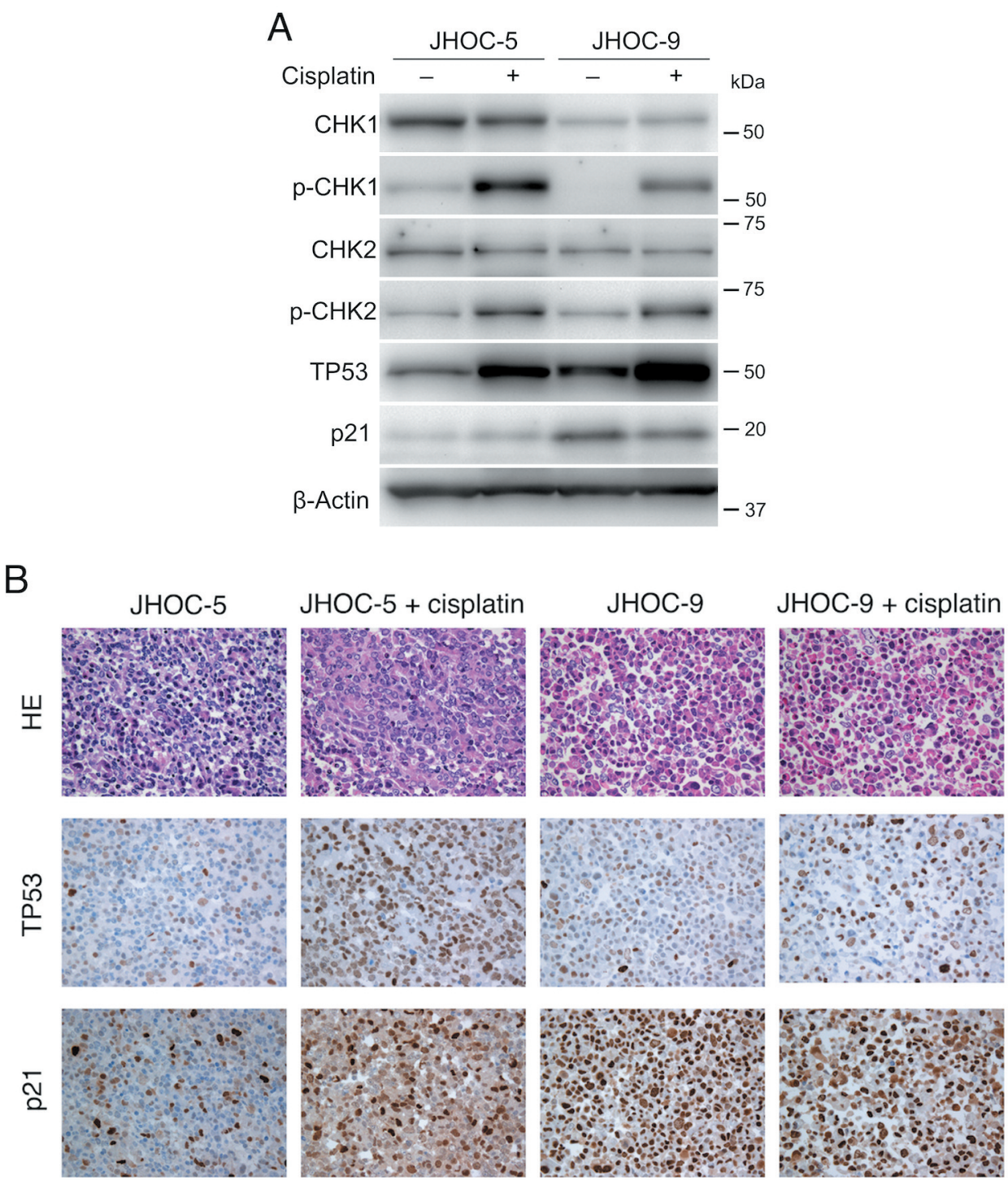

Figure 2. Expression and phosphorylation of molecules in DNA-damage response of cultured ovarian clear-cell cancer cell lines JHOC-5 and JHOC-9 treated with $10 \mu \mathrm{g} / \mathrm{ml}$ cis-diamminedichloridoplatinum(II) (cisplatin) for $24 \mathrm{~h}$. A: Western blot analysis. B: Immunohistochemical staining of cell block sections.

results indicate that $\mathrm{p} 21$ inhibition is more likely to reduce cell viability, causing cell death in CCC cells with high p21 expression compared to those with low p21 expression.

\section{Discussion}

The present study investigated molecular expression during DDR occurring in CCC using surgical sections and two types of cultured cells. We first evaluated IHC expression of CHK1, CHK2, and TP53 in DDR (Figure 1 and 5). Half of our cases demonstrated high p21 expression, whereas the remainder exhibited low p21 expression. In treated cultured CCC cells, phosphorylation or activation of CHK1, CHK2, and TP53 was also identified. There was a different pattern of $\mathrm{p} 21$ expression between the cell types. Prior to stimulation, p21 was constitutively expressed in JHOC-9 cells, whereas its expression was minimal in JHOC-5 cells. p21 Inhibition by UC2288 reduced cell viability in both JHOC-5 and JHOC-9 cells; however, its suppressive effect was more substantial in JHOC-9 cells causing cell death, which was confirmed by cleaved caspase- 3 activation.

We examined the DDR pathway in cultured CCC cells and found that $\mathrm{CHK} 1$ and $\mathrm{CHK} 2$ were phosphorylated after incubation with cisplatin, indicative of preserved functions 


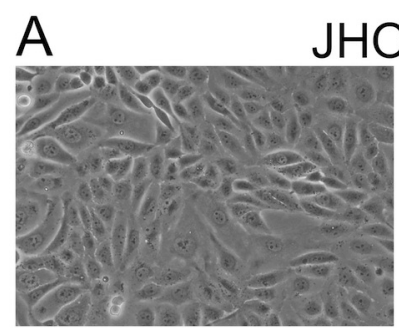

Untreated

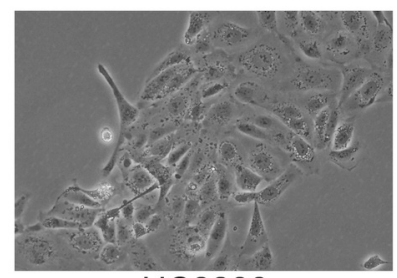

UC2288
JHOC-5

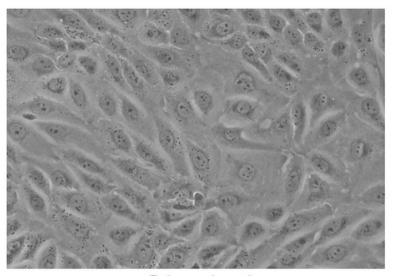

Cisplatin

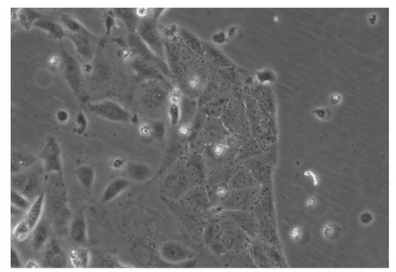

Cisplatin + UC2288

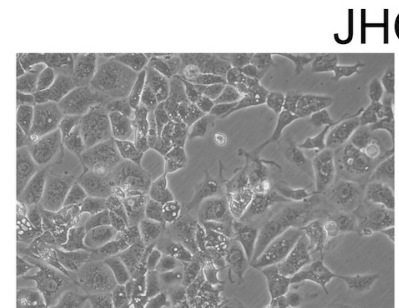

Untreated

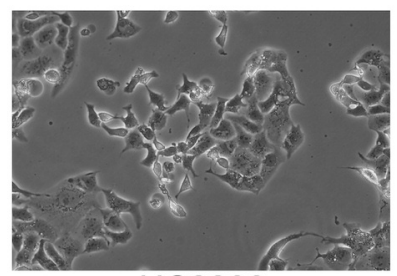

UC2288
JHOC-9

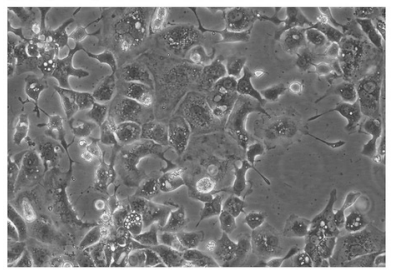

Cisplatin

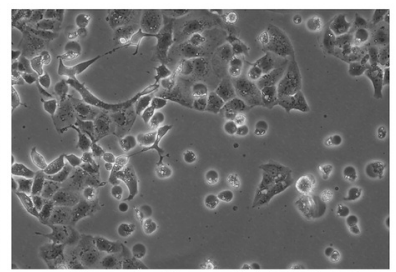

Cisplatin + UC2288
B

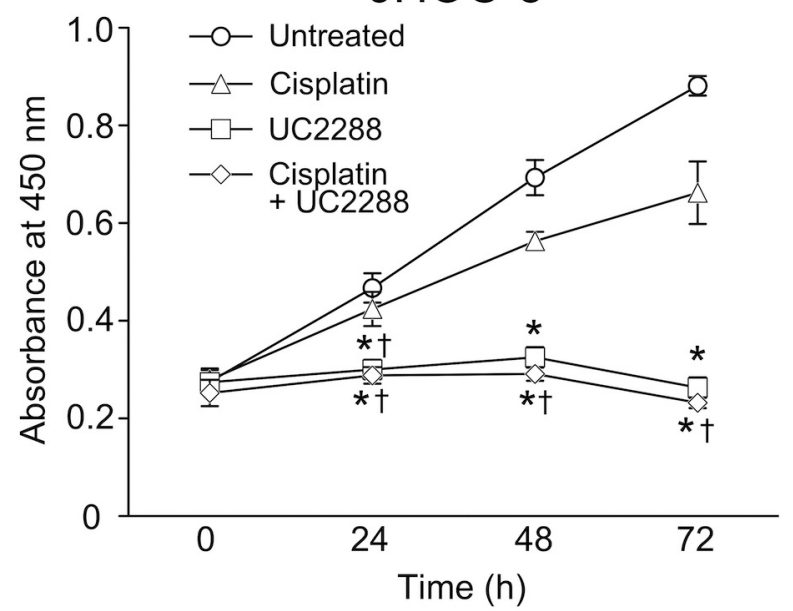

JHOC-5

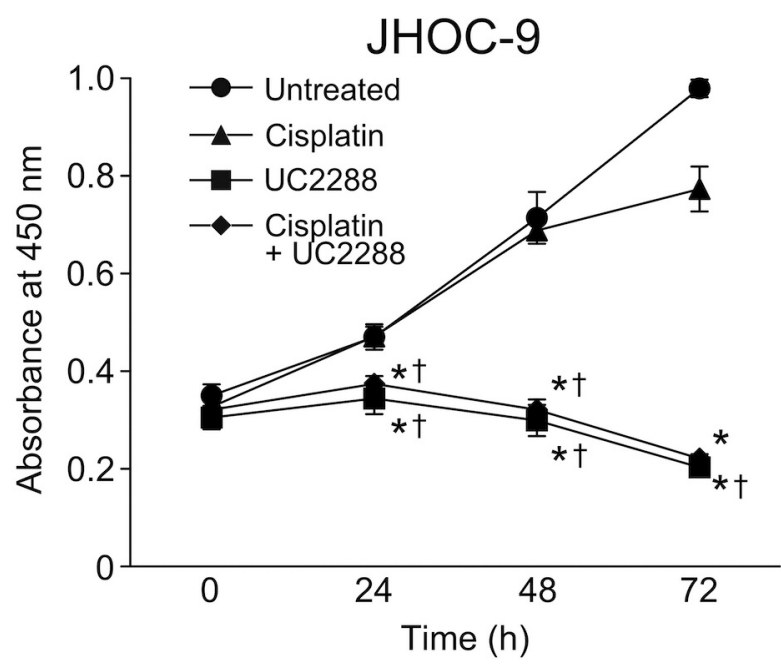

Figure 3. Cultured cells were treated with $10 \mu \mathrm{g} / \mathrm{ml}$ cis-diamminedichloridoplatinum(II) (cisplatin) or $10 \mu M$ UC2288, a p21-specific inhibitor, or their combination and proliferation was analysed. A: The microscopic appearance of JHOC-5 and JHOC-9 cells treated for 24 h. B: Proliferation of JHOC-5 and JHOC-9 cells. Significantly different at $* p<0.01$ vs. untreated; ${ }^{\dagger} p<0.05$ vs. cisplatin.

upstream of DDR. TP53 expression level increased in JHOC9 cells, which may be due to TP53 mutation (17), compared with that of JHOC-5 cells. p21 Exerts multiple functions during DDR; it determines whether a cell goes through the cell cycle or undergoes death, depending on the microenvironment $(4,5,18)$. Although the precise mechanism of enhanced p21 expression remains unclear, there are a few hypotheses. The first possibility is that increased p21 expression may represent a response to non-functioning mutated TP53. The second is that high expression of $\mathrm{p} 21 \mathrm{can}$ be driven by overexpression of mutated TP53. Some studies reported that transcription of $p 21$ is induced by TP53 $(5,18$, 19). A third possibility is a genetic alteration in molecules regulating p21 expression. In our study, it should be noted that UC2288, an attenuator of p21, suppressed cell proliferation and induced apoptotic cell death. As the suppressive effect of UC2288 was observed in both cell lines, it is probable that the effect was induced regardless of the mutational status of TP53. Other researchers have demonstrated that $\mathrm{p} 21$ can be degraded by ubiquitination (13, 14). Further studies are necessary to determine the molecular alterations in UC2288 treated CCC cells.

Itamochi et al. showed that inhibition of DDR-related molecules, including CHK1, CHK2 and CDK inhibitor p27, with small molecule inhibitor suppressed the proliferation of CCC cell lines $(11,12)$, showing that DDR molecules may be potential targets for CCC treatment. However, these inhibitors are not yet clinically applied. Here, we demonstrated that 
A

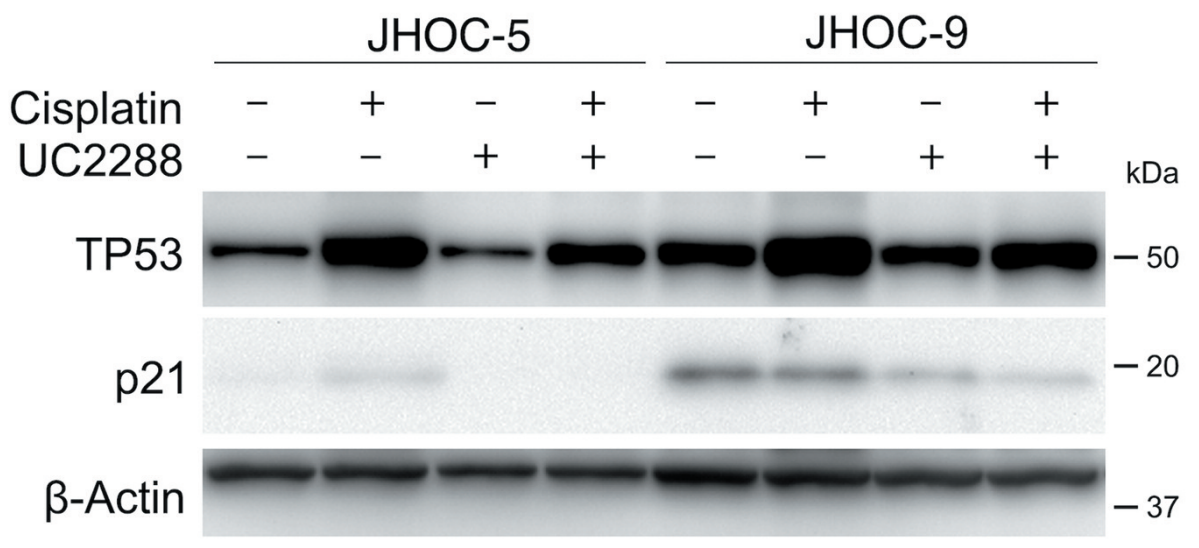
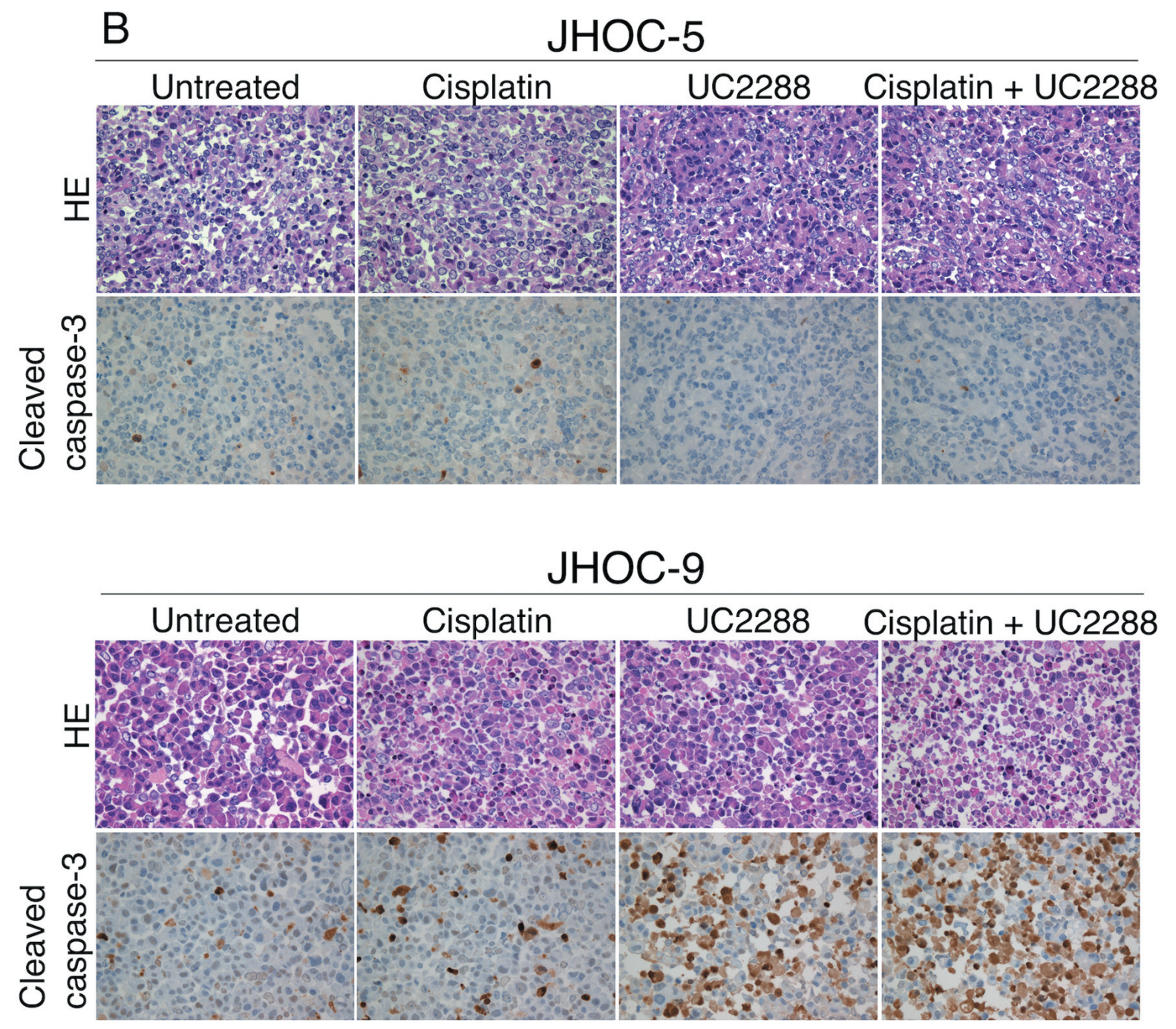

Figure 4. Cultured cells were treated with $10 \mu \mathrm{g} / \mathrm{ml}$ cis-diamminedichloridoplatinum(II) (cisplatin) or $10 \mu M$ UC2288, a p21-specific inhibitor, or their combination for $24 \mathrm{~h}$ and then analysed for proteins involved in determining cell fate. A: Western blot analysis of JHOC-5 and JHOC-9 cells. B: Immunohistochemical staining of cleaved caspase-3 in JHOC-5 and JHOC-9 cell blocks. 


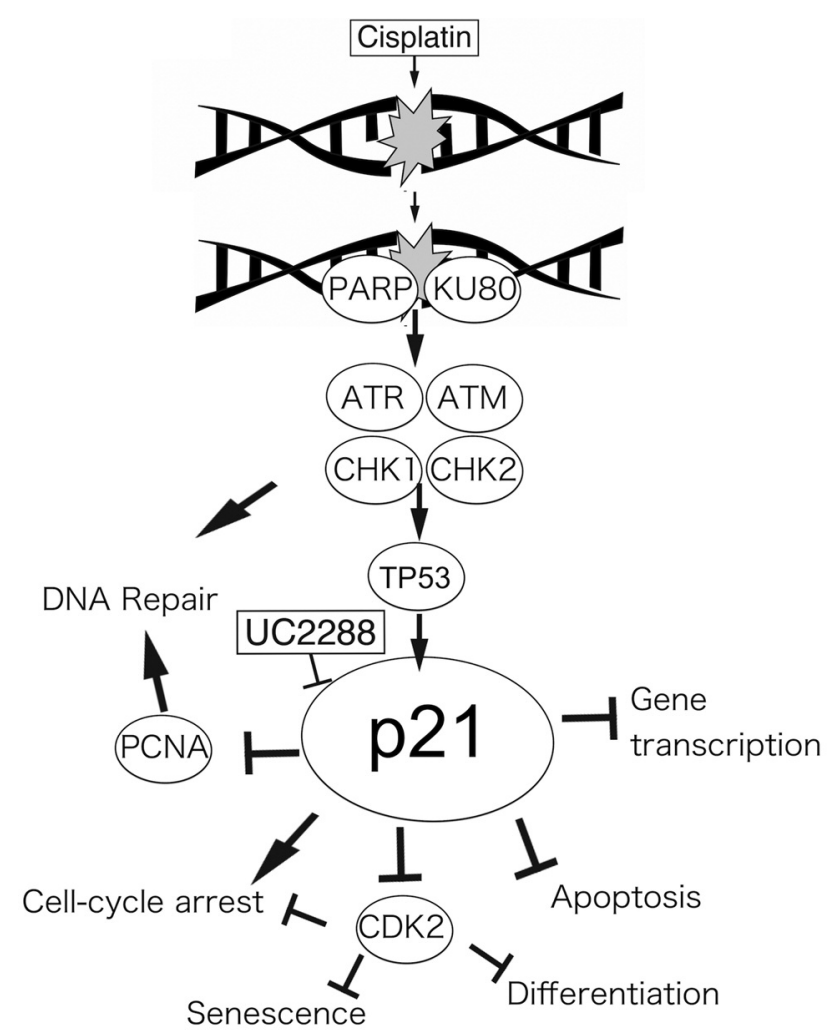

Figure 5. The signalling pathway of the DNA-damage response. PARP: Poly (ADP ribose) polymerase; KU80: 80-kDa Ku protein; ATR: ATMand RAD3-related; ATM: ataxia-telangiectasia mutated; CHK1: checkpoint kinase 1; CHK2: checkpoint kinase 2; TP53: tumour protein p53; p21; 21-kDa protein; PCNA: proliferating cell nuclear antigen; CDK2: cyclin-dependent kinase 2.

growth of CCC cell lines was inhibited by a UC2288. To our knowledge, this is the first report to demonstrate the anticancer property of a p21 inhibitor in CCC cell lines. Although p21 acts as an inhibitor of CDK in the nucleus, it also acts as a regulator of cell death in the cytoplasm. p21 binds to caspase3 and inhibits cleavage and transformation to the activated form of caspase-3 (20). Additionally, it was shown that p21 forms a complex with apoptosis signal-regulating kinase 1 and inhibits the apoptosis signal (4). Therefore, it is conceivable that UC2288 attenuates the inhibitory effect of the p21dependent mechanism on pro-apoptotic molecules in cytoplasm. Our findings, in which caspase-3 cleavage was enhanced in JHOC-9 cells supports this hypothesis. However, the exact aetiology underlying the different expression levels of p21 between JHOC-5 and JHOC-9 cells leading to a subsequent cellular response is unclear, and additional studies may reveal the mechanism in future.

Nuclear expression of p21 was documented in renal cell carcinoma (RCC) (21), prostate cancer (22), breast cancer (23), and ovarian cancer $(24,25)$. Others demonstrated that enhanced nuclear expression of p21 was associated with a favourable clinical course in localized RCC (21) and ovarian cancer (25), whereas the opposite was reported in metastatic RCC (21) and prostate cancer (22). In the present study, we classified surgical sections from patients with CCC into groups with high and low p21 expression. However, we were unable to demonstrate an association between the p21 expression pattern and patients' clinicopathological characteristics. This is because most patients had disease at an early pathological stage and were followed-up for a short period of time. Based on our findings, in which UC2288 induced death in cells with high p21 expression, it is anticipated that UC2288 may serve as a therapeutic agent to treat patients with CCC highly expressing p21. However, future studies using a larger cohort of patients with CCC with a longer follow-up period are required to validate our hypothesis.

\section{Conflicts of Interest}

The Authors declare no conflicts of interest and that no funding was received for this study.

\section{Authors' Contributions}

$\mathrm{YM}, \mathrm{KI}$, and RW were involved in the conception and design of the study. YM, RW, and RO performed the histological examination and analysis. YM, KI, and TT acquired the clinical data. YM and KI performed the biological and cell culture experiments. YM, KI, RW, and RO analysed and interpreted the data. RW and MK performed the statistical analysis. YM, KI, and RW drafted the manuscript. MK, ZN, TT and RO provided critical revisions to the article. All Authors read and approved the final article.

\section{Acknowledgements}

The Authors would like to acknowledge the excellent assistance of Ms Kiyoko Kawahara for cell culture, Mr Takenori Fujii and Ms Yoko Kawamoto for help with histology and immunohistochemical staining, and Mr Kiyoshi Teduka for help with western blot analysis (Department of Integrated Diagnostic Pathology, Nippon Medical School, Tokyo, Japan).

\section{References}

1 Blanpain C, Mohrin M, Sotiropoulou PA and Passegue E: DNAdamage response in tissue-specific and cancer stem cells. Cell Stem Cell 8: 16-29, 2011. PMID: 21211780. DOI: 10.1016/ j.stem.2010.12.012

2 Dasari S and Tchounwou PB: Cisplatin in cancer therapy: Molecular mechanisms of action. Eur J Pharmacol 740: 364-378, 2014. PMID: 25058905. DOI: 10.1016/j.ejphar.2014.07.025

3 Shigetomi H, Higashiura Y, Kajihara $\mathrm{H}$ and Kobayashi $\mathrm{H}$ : Targeted molecular therapies for ovarian cancer: An update and future perspectives. Oncol Rep 28: 395-408, 2012. PMID: 22641286. DOI: 10.3892/or.2012.1833 
4 Dutto I, Tillhon M, Cazzalini O, Stivala LA and Prosperi E: Biology of the cell cycle inhibitor p21(CDKN1A): Molecular mechanisms and relevance in chemical toxicology. Arch Toxicol 89: 155-178, 2015. PMID: 25514883. DOI: $10.1007 /$ s00204014-1430-4

5 Kreis NN, Louwen $\mathrm{F}$ and Yuan J: The multifaceted p21 (CIP1/WAF1/CDKN1A) in cell differentiation, migration and cancer therapy. Cancers 11: 1220, 2019. PMID: 31438587 . DOI: $10.3390 /$ cancers 11091220

6 Cazzalini O, Scovassi AI, Savio M, Stivala LA and Prosperi E: Multiple roles of the cell cycle inhibitor p21(CDKN1A) in the DNA damage response. Mutation Res 704: 12-20, 2010. PMID: 20096807. DOI: 10.1016/j.mrrev.2010.01.009

7 Gartel AL and Tyner AL: The role of the cyclin-dependent kinase inhibitor p21 in apoptosis. Mol Cancer Ther 1: 639-649, 2002. PMID: 12479224

8 Machida H, Matsuo K, Yamagami W, Ebina Y, Kobayashi Y, Tabata T, Kanauchi M, Nagase S, Enomoto T and Mikami M: Trends and characteristics of epithelial ovarian cancer in Japan between 2002 and 2015: A JSGO-JSOG joint study. Gynecol Oncol 153: 589-596, 2019. PMID: 30905436. DOI: 10.1016/j.ygyno.2019.03.243

9 Takahashi K, Takenaka M, Kawabata A, Yanaihara N and Okamoto A: Rethinking of treatment strategies and clinical management in ovarian clear-cell carcinoma. Int J Clin Oncol 25: 425-431, 2020. PMID: 31989349. DOI: 10.1007/s10147020-01625-w

10 Chan JK, Teoh D, Hu JM, Shin JY, Osann K and Kapp DS: Do clear-cell ovarian carcinomas have poorer prognosis compared to other epithelial cell types? A study of 1411 clear-cell ovarian cancers. Gynecol Oncol 109: 370-376, 2008. PMID: 18395777. DOI: 10.1016/j.ygyno.2008.02.006

11 Itamochi H, Nishimura M, Nishimura M, Oumi N, Kato M, Oishi T, Shimada M, Sato S, naniwa J, Sato S, Kudoh A, Kigawa $\mathrm{J}$ and Harada T: Checkpoint kinase inhibitor AZD7762 overcomes cisplatin resistance in clear cell carcinoma of the ovary. Int J Gynecol Cancer 24(1): 61-69, 2014. PMID: 24362713. DOI: $10.1097 /$ IGC.0000000000000014

12 Itamochi H, Yoshida T, Walker CL, Bartholomeusz C, Aoki D, Ishihara $\mathrm{H}$, Suzuki N, Kigawa J, Terakawa $\mathrm{N}$ and Ueno NT: Novel mechanism of reduced proliferation in ovarian clear cell carcinoma cells: Cytoplasmic sequestration of CDK2 by p27. Gynecol Oncol 122: 641-647, 2011. PMID: 21652059. DOI: 10.1016/j.ygyno.2011.05.003

13 Liu R, Wettersten HI, Park SH and Weiss RH: Small-molecule inhibitors of p21 as novel therapeutics for chemotherapyresistant kidney cancer. Future Med Chem 5(9): 991-994, 2013. PMID: 23734682. DOI: 10.4155/fmc.13.56

14 Wettersten HI, Hwang SH, Li C, Shiu EY, Wecksler AT, hammock BD and Weiss RH: A novel p21 attenuator which is structurally related to sorafenib. Cancer Biol Ther 14: 278-285, 2013. PMID: 23298903. DOI: $10.4161 /$ cbt.23374

15 Tay VSY, Devaraj S, Koh T, Ke G, Crasta KC and Ali Y: Increased double-strand breaks in diabetic $\beta$-cells with a p21 response that limits apoptosis. Sci Rep 9(1): 19341, 2019. PMID: 31852915. DOI: 10.1038/s41598-019-54554-8

16 Lee HJ, Xu X, Choe G, Chung DH, Seo JW, Lee JH, Lee CT, Jheon S, Sung SW and Chung JH: Protein overexpression and gene amplification of epidermal growth factor receptor in nonsmall cell lung carcinomas: Comparison of four commercially available antibodies by immunohistochemistry and fluorescence in situ hybridization study. Lung Cancer 68(3): 375-382, 2010. PMID: 19712993. DOI: 10.1016/j.lungcan.2009.07.014

17 Kashiyama T, Oda K, Ikeda Y, Shiose Y, Hirota Y, Inaba K, Makii C, Kurikawa R, Miyasaka A, Koso T, Fukuda T, Tanikawa M, Shoji K, Sone K, Arimoto T, Wada-Hiraike O, Kawana K, Nakagawa S, Matsuda K, McCormick F, Aburatani H, Yano T, Osuga Y and Fujii T: Antitumor activity and induction of TP53dependent apoptosis toward ovarian clear cell adenocarcinoma by the dual PI3K/mTOR inhibitor DS-7423. 9(2): e87220, 2014. PMID: 24504419. DOI: 10.1371/journal.pone.0087220

18 Abbas T and Dutta A: p21 In cancer: Intricate networks and multiple activities. Nat Rev Cancer 9: 400-414, 2009. PMID: 19440234. DOI: $10.1038 / \mathrm{nrc} 2657$

19 Al Bitar S and Gali-Muhtasib H: The role of the cyclindependent kinase inhibitor $\mathrm{p} 21 \mathrm{CIP} 1 / \mathrm{WAF} 1$ in targeting cancer: Molecular mechanisms and novel therapeutics. Cancers 11: 1475, 2019. PMID: 31575057. DOI: 10.3390/cancers11101475

20 Suzuki A, Tsutomi Y, Akahane K, Araki T and Miura M: Resistance to Fas-mediated apoptosis: Activation of caspase 3 is regulated by cell cycle regulator $\mathrm{p} 21^{\mathrm{WAF} 1}$ and IAP gene family ILP. Oncogene 17: 931-939, 1998 PMID: 9747872. DOI: 10.1038/sj.onc. 1202021

21 Robert HW, Borowsky AD, Seligson D, Lin PY, Dillard-Telm L, Belldegrun AS, Figlin RA and Pantuck AD: p21 Is a prognostic marker for renal cell carcinoma: implications for novel therapeutic approaches. J Urol 177: 63-69, 2007. PMID: 17162001. DOI: 10.1016/j.juro.2006.08.073

22 Baretton GB, Klenk U, Diebold J, Schmeller N and Löhrs U: Proliferation- and apoptosis-associated factors in advanced prostatic carcinomas before and after androgen deprivation therapy: Prognostic significance of p21/WAF1 in advanced prostate cancer. Br J Cancer 80(3-4): 546-555, 1999. PMID: 10408865. DOI: $10.1038 /$ sj.bjc. 6690390

23 Zohny SF, Al-Malki AL, Zamzami MA and Choudhry H: p $21^{\mathrm{WAF} 1 / \mathrm{CIP} 1}$ : Its paradoxical effect in the regulation of breast cancer. Breast Cancer 26(2): 131-137, 2019. PMID: 30255294. DOI: $10.1007 / \mathrm{s} 12282-018-0913-1$

24 Shimizu M, Nikaido T, Toki T, Shiozawa T and Fujii S: Clear-cell carcinoma has an expression pattern of cell cycle regulatory molecules that is unique among ovarian adenocarcinomas. Cancer 85(3): 669-677, 1999. PMID: 10091740. DOI: 10.1002/(sici)10970142(19990201)85:3<669::aid-cncr17>3.0.co;2-f

25 Anttila MA, Kosma VM, Puolakka J, Juhola M, Saarikoski S and Syrjänen: p21/WAF1 Expression as related to p53, cell proliferation and prognosis in epithelial ovarian cancer. $\mathrm{Br} \mathrm{J}$ Cancer 79(11/12): 1870-1878, 1999. PMID: 10206307. DOI: 10.1038/sj.bc.6690298

26 Prat J and FIGO Committee on Gynecologic Oncology: Staging classification for cancer of the ovary, fallopian tube, and peritoneum. Int J Gynaecol Obstet 124(1): 1-5, 2014. PMID: 24219974. DOI: 10.1016/j.ijgo.2013.10.001
Received July 31, 2020

Revised August 14, 2020

Accepted August 23, 2020 